\title{
THE ABILITY OF THE ELEVENTH GRADE STUDENTS OF SMA DELI MURNI BANDAR BARU ON USING COUNTABLE ANDUNCOUNTABLE NOUNS IN THE ACADEMIC YEAR OF 2020/2021
}

\author{
Tesalonika Br Karo ${ }^{1,}$ Viator Lumbanraja ${ }^{2}$, Novalina Sembiring ${ }^{3}$ \\ ${ }^{123}$ Universitas Katolik Santo Thomas Medan, Indonesia \\ Email :tesalonika_karo@gmail.com, viator_lumbanraja@ust.ac.id ${ }^{2}$, \\ novalina_sembiring@ust.ac.id ${ }^{3}$
}

The purpose of this research is to describe the ability of the eleventh-grade students of SMA Deli Murni Bandar Baru on using Countable and Uncountable Nouns. The population of this research was the eleventh-grade students, with 58 students taken as sample. The instrument of collecting data is a test concerning Countable and Uncountable Nouns. The tryout test was done to know the validity, reliability, item difficulty of test items. The result showed that 5 students $(15 \%)$ belong to the high category, 24 students (73\%) to the moderate category, and 4 students (12\%) to the low category. The mean score was 61,39 it was only $24 \%$ of the total students who can do the test well with 12 students who get a score above 75 , it means that the eleventh-grade students of SMA Deli Murni Bandar Baru are not yet able to use Countable and Uncountable Nouns. Based on the total incorrect answers made by the students in using countable and uncountable was 502. The percentage of students' mistakes made by students in uncountable multiple choice including indefinite and quantifier uncountable was $33 \%$, in countable multiple choice including singular, regular, irregular countable $34 \%$, in the countable essay including regular and irregular countable was 33\%. Based on the findings and conclusions, some suggestions are offered to English teachers, English students, and other researchers. Especially to English teachers, who teach in school, are advised to improve students' ability to use countable and uncountable nouns.

Key Words: Ability, Countable nouns, Uncountable nouns.

\section{INTRODUCTION}

\subsection{The Background of the Study}

English is an important language in the world because it is widely spoken among countries. According to Blackwell (2014: 571) "English is perhaps the single most important linguistic source for the promotion of global bilingualism and for linguistic creativity." When two countries meet and come with different languages, they usually use English to communicate. Even in an international conference or seminar, English is used as a means of communication. That English has a prominent role to bridge among nations is acknowledge.

In learning a language one cannot escape from grammar that is the rules of language to form sentences. The basic part of a sentence is noun phrase and verb phrase. One of the English grammar is parts of speech which are divided into two parts they are content words and function words. One of parts of speech is noun which also has a big number than others. It can include person country, thing, city, idea, etc. Noun divided into proper and common nouns, abstract and concrete nouns, countable and uncountable nouns and the last is collective noun. Proper noun is a classification of nouns for people, places, and other things that are more 
specific. It is opposite with common noun which is used to express a general object. Whereas abstract noun is a noun that cannot be observed with the five senses, Concrete noun is a noun that can be observed with the five sense. Then collective noun is that noun which represents a unity in a word group of objects, animals and also humans like a cup of coffee, a bucket of flower, a piece of cake and etc. Countable noun are nouns that we can be count as singular and plural form. Uncountable nouns are objects that cannot be count or mass objects for example chemicals, gases, metals, and material such as sugar, sand, coffee, milk, air etc. According to Harber \& Payton (2001: 1206), "Countable or uncountable nouns, countable nouns can be counted and so have a plural: cat, table. Uncountable nouns cannot be counted and do not have plural: information, health. Concrete or abstract, concrete nouns refer to things you can touch, taste, hear, see or smell: table, orange. Abstract nouns refer to thoughts, feelings, and ideas which cannot be touched: beauty, safety. Proper or common, proper nouns are names of people, place, month , days: Victoria, Tuesday. Common nouns are all the noun."

In this research the writer focuses on countable and uncountable noun because based on writer's experience during the teaching practice in Senior High School at Deli Murni Bandar Baru in tenth grade students. She taught the students about noun, including countable and uncountable noun. Based on curriculum 2013 they have learned about countable and uncountable nouns in junior high school, because of that the students should have mastered the use of nouns especially countable and uncountable noun but in fact, based on the writer's observation most of the students are unable to use countable and uncountable nouns correctly.

This can be seen in the following exam plus which the students write.

1. How many bread that I should bring?

2. I have so many sugar.

In the sentence (1) students make mistakes, namely in the use of many and much, because bread is an uncountable form that should use much. Same as sentence (2) where sugar is a form of uncountable noun, then it should use much form.

The writer found out that the students were not able to distinguish singular and plural forms of noun which also affect the verb. For examples:

1. We are strong woman.

2. I have one dog, two cats and three mouses.

In sentence (1) there is mistake in the word woman. Woman must be replaced by women because the sentence (1) uses to be are which means more than one object. While woman is a singular form therefore woman must be replaced by women which is plural form of woman. In the sentence (2) there is a mistake in the singular and plural form of the mouses.

This research is entitled "The Ability of The Eleventh Grade Students of SMA Deli Murni Bandar Baru on Using Countable and Uncountable Nouns in the Academic Year of 2020/2021".

\section{REVIEW OF LITERATURE}

\subsection{The Definition of Ability}

Ability comes from the word "able" and the suffix of "-ity" where able have the meaning as skill, having power, or the opportunity to do something. Whereas suffix -ity is a noun marker attached to adjectives to form nouns such as sensibility, 
readability, etc. Thus, the definition of ability is the quality of being able to do something. According to Sanford (2012: 23), "Ability is the quality of being able to do something including capacity, competence, talent, skill, and aptitude". Besides, Robbins \& Timonthy (2014: 42) say "Ability is an individual's current capacity to perform the various takes in the job". From the statement above can be concluded that ability means potential, knowledge, skill in which someone has to do something well and this potential comes naturally or comes by learning. The quality of being able to do something or act physically and mentally to accomplish something. The level of ability is a measure of the success of learners to remember what they have get.

\subsection{Types of Ability}

Ability is divided into two types they are physical and intellectual. According to Haffman \& Farrel (2007: 174), one way of defining ability is to say it is a person's capacity to perform the various tasks that a job entails. When looking at individual capabilities, the ability is made up of two sets of factors, namely physical and intellectual

1. Physical Ability

Physical abilities are individuals who can physically perform important functions of a job without risking injury like others. For example dancing, swimming, relay jumping, etc. Robbins \& Judge (2013: 485) state that physical ability is the capacity to do tasks demanding stamina, dexterity, strength, and similar characteristic.

2. Intellectual Ability

Intellectual abilities are abilities that are measured by performance on intelligence tests. Sometimes it is also used in the context of discussing a person's performance in an academic or real-world environment. According to Robbins \& Judge (2013: 483), intellectual ability is the capacity to do mental activities such as thinking, reasoning, and problem-solving.

\subsection{Content Word}

Content words are usually nouns, verbs, adjectives, and adverbs. A noun tells us which object, a verb tells us about the action happening, or the state. Adjectives give us details about objects and people and adverbs tell us how, when or where something is done. Nouns, verbs, adjectives and adverbs give us important information required for understanding. According to Denham \& Lobeck (2010:144) Nouns, verb, adjective, and adverbs are all content word. Besides that Bian and Guo (2019: 108) states that content words mainly include nouns, verbs, adjectives, and adverb.

\subsection{Definition of Nouns}

Noun is a word used to name people, objects, animals, places, and idea. Noun is one of the eight parts of speech. According to Atlee (2005: 32), a noun is the words that names a person, place, thing, idea or quality. Besides that Kriszner \& Mandell (2007: 199), states nouns name people, animals, places, thing, ideas, actions, or qualities. Based on explanation above, it can be known that noun is word that names something such as person, a place, a thing, an idea and a quality. Their appearance is marked by the article, while adding /s/ that signal pluralism. 


\subsection{Types of Noun}

Nouns divided into several types they are, proper and common nouns, concrete and abstract nouns, countable and uncountable (mass) nouns and the last is collective nouns. Based on Blakesley \& Hoogeven (2012: 435) they distributed the nouns as below:

\begin{tabular}{|c|c|c|}
\hline $\begin{array}{l}\text { Proper } \\
\text { Tony hawk } \\
\text { Vancouver } \\
\text { Hyundai }\end{array}$ & $\begin{array}{l}\text { Common } \\
\text { man } \\
\text { city } \\
\text { car }\end{array}$ & $\begin{array}{l}\text { Concrete } \\
\text { bed } \\
\text { wind } \\
\text { bells }\end{array}$ \\
\hline $\begin{array}{l}\text { Collective } \\
\text { Team } \\
\text { Faculty } \\
\text { Army }\end{array}$ & $\begin{array}{l}\text { Countable } \\
\text { players } \\
\text { Classmates } \\
\text { Soldiers }\end{array}$ & $\begin{array}{l}\text { Uncountable } \\
\text { team spirit } \\
\text { homework } \\
\text { equipment }\end{array}$ \\
\hline
\end{tabular}

\subsubsection{Proper and Common Nouns}

Proper noun is a classification of nouns for people, places, and other things that are more specific. Blakesley \& Hoogeveen (2012: 559) state Proper nouns name specific people, place, time periods, events, groups, or things. They must be capitalized. They usually do not take determiners. Opposite with proper noun, common noun are names of people, places, things, or ideas in general. Common noun is the name of a group of similar or similar nouns. Because the common noun does not name anything specifically, it is not written in capital letters, except at the beginning of the sentence. This statement is supported by Brown. According to Brown (2008: 9), Common noun name general kinds of people, places, things, and ideas (e.g., ponies, month, Frostbite).

\subsubsection{Abstract and concrete Nouns}

An abstract noun is a noun that cannot be observed with the five senses, cannot be seen, touch, smell, hear, and has no physical form. According to Lapworth (2011: 6), Abstract nouns - names of things you cannot physically touch or see (direction, poverty, beauty, hope, faith). Concrete nouns opposite with abstract noun cause Concrete nouns is a noun that can be seen by five senses, can be seen and touch. Concrete nouns refer to physical things rather than qualities, circumstances, or actions such as houses, books, horses, Pen, etc. Dalmolin (2009: 179') states "Nouns that have proper existence that one can see, touch, hear, smeller or taste are called concrete nouns." A few examples of concrete nouns are door, car, sweeper, CD player, truck.

\subsubsection{Collective Noun}

Sings (2015: 210) states "Collective noun it is the name of the collection or a group of persons and things treated as a whole. For example, class, pack, crowd, committee, fleet, gang, batch.

\subsection{Countable and Uncountable Nouns}

Noun types are further divided into two based on nouns that can be counted or not, there are called countable and uncountable noun. 


\subsubsection{Countable Noun}

A countable noun is a noun that can be counted directly. Countable nouns (count noun) have both singular and plural form. For example (book/books, chair/chairs). In the singular, they can use by article $a$ or $a n$.

\subsubsection{Singular \& Plural Countable Nouns}

Countable nouns are thing which can be counted and divided into two forms they are singular and plural forms.

\section{a. Singular form}

The singular form can use the determiner "a" or "an". Gangal (2011:68) states "A singular countable noun is always used with a/an". For example a book, an apple, a car, a baby.

\section{b. Plural form}

Nouns can change from singular to plural. From one to more than one, several or many. There are two types of changes, namely regular and irregular. According to Blakesley \& Hoogeveen (2012: 562), the plural form of a regular countable noun is created by adding $s$ or $e s$ to the singular form.

\subsubsection{Uncountable Noun}

Uncountable nouns or also called mass nouns are nouns that cannot be counted. Uncountable nouns can also be remembered as nouns that have only one form, singular form, uncountable nouns cannot change to the plural form. An example is water.

\subsubsection{Indefinite Pronouns in countable and uncountable nouns}

An indefinite pronoun is a pronoun that refers to objects, objects, or anything that is not specific. The indefinite pronoun has a singular and plural form. In some cases, indefinite pronouns can be used as singular or plural pronouns. The following are some types of pronouns which include Indefinite Pronoun Quantity: Some, any, both, much, many, few, less. Plenty of, a lot of, etc. below is some indefinite pronouns relating to countable and uncountable nouns.

\section{Many and much}

"Many" are used to declare objects that can be counted or what we call countable nouns. Singh (2019:11) states "Countable nouns are preceded by indefinite articles a/an and other determines, such as many, few, number, of, each, every, etc.

\section{Few and Little}

Few and little have the same meaning, but there was a difference between them, namely: The word few is used for countable nouns and the word little refers to uncountable nouns.

\section{Some and Any}

These two words are usually used to express nouns that have an indeterminate number of plural countable nouns or uncountable nouns. As written by Bestiana and Achyani in their book:

We can use some and any with plural countable nouns:

- We sang some songs

- Did you buy any apples?

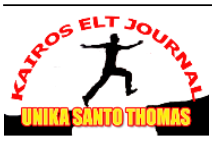


We can use some and any with uncountable nouns:

- We are listening to some music.

\section{RESEARCH METHOD}

\subsection{Research Design}

This research was quantitative descriptive research. Quantitative descriptive research is an investigation of phenomena that are systematically described by gathering quantifiable data and performing statistical, mathematical, or computational techniques. Quantitative research collects information from existing and potential customers using sampling methods, tests, interviews, questionnaires, and sending online surveys, online polls, etc. Ramadass \& Waruni, (2014: 27) states the objective of quantitative research is to develop and employ mathematical models, theories and hypotheses pertaining to natural phenomena. The process of measurement is central to quantitative research because it provides the fundamental connection between empirical observation and mathematical expression of quantitative relationships. Quantitative data is numerical form such as statistics, percentages, etc.

\subsection{The Location and the Time of the Study}

The research was conducted at SMA Deli Murni especially at class XI which is located at Bandar Baru. The writer chooses the school because based on the preliminary observation that was done by the writer, some of the students were not able to use a countable and uncountable noun. This could be seen when the teachers were teaching this topic. There are four classes of the eleventh grade students of Deli Murni Bandar Baru. But the writer choose two classes to conducted her research.

\subsection{The Population and Sample}

\subsubsection{Population}

The population of this research was the eleventh-grade students of SMA Deli Murni Bandar Baru in the Academic year of 2020/2021. There are 130 Students as the population of these studies which consists of four classes.

\subsubsection{Sample}

Jonhson \& Christense (2008: 223) define that sample is set of element taken from a large population. The writer takes sample from two classes they are XI Antonious Padua (XI MIA A) and XI IPS A, 25 students from XI IPS A and 33 students from XI MIA A. So the total of sample was 58 students.

\section{4 Technique in Collecting the Data}

To obtain some data that were need to support this research, the writer applies the following technique as follows:

\subsubsection{Try Out}

The writer gave a try out first to find out how reliable and valid it was done with the test statistics. Try out was carry out to identify how valuable and effective the test is before it would be used to collect research data and identify whether the 
test is feasible or not. It can be seen from the results of the reliability and validity of the test. The try out will be carried out in XI IPS A.

\subsection{The Instrument of Collecting Data}

This instrument used to collect the data is a test which concerns countable and uncountable nouns. The test would been administered to the students via WhatsApp groups. The The Test would be taken 40 items in multiple choices, for try out, then 25 items chosen to be the real test. 15 more items on completion test were added for try out, then 10 items in the real test. Therefore the total questions in the try out are 55 items and in the real test are 35 items. The time limit will be given in answering questions in the real test which is for 90 minutes to answer 35 questions. A tryout test will be carried out in eleventh grade students at SMAN 1 Bandar Baru.

\subsection{Validity and Reliability Data}

An instrument can be used to be good one if it is valid and reliable. Before the instrument are used, they have to be tried out. It is intended to find out the validity and reliability of the instrument.

\subsubsection{Validity}

Valid means the instrument can be used to measure what should be measured. A valid instrument has high validity. Conversely, a less valid instrument means having low validity. Schmidt \& Brown (2012:228) state that a valid instrument reflects the characteristics or concept that is being measured. According to Johnson and Christensen (2008:150) "validity is the accuracy of the inferences, interpretations or actions made on the base of the test scores". In this research, the writer uses content validity. Content validity is the degree a test measures an intended content area. It ensures that the measurement includes an adequate set of items. Content validity is carried out to ascertain whether the contents of the questionnaire are appropriate and relevant to the purpose of the study. Furthermore, one of the characteristics of a good test in content validity in which the test materials are constructed based on the curriculum. The test the writer give to students is a test that they had learned precisely in ninth grade in junior high school and studied again in tenth grade according to Syllabus precisely in chapter 7 , it means that the test is valid.

\subsubsection{Reliability}

Reliability is the consistency or stability of a set of test scores. The writer uses the calculation method from Arikunto to see the reliability of the test. Their range ability uses the formula by Arikunto (2012:49) as follows:

$$
r_{x y}=\frac{n \sum x y-\left(\sum x\right)\left(\sum y\right)}{\left.\sqrt{\left(n \sum x^{2}\right.}-\left(\sum x^{2}\right)\right) \cdot\left(n \sum y^{2}-\left(\sum y\right)^{2}\right.}
$$

$$
\begin{aligned}
& r_{x y}=\text { The coefficient correlation between variable } \mathrm{x} \text { and } \mathrm{y} \\
& \mathrm{X}=\text { The odd number test } \\
& \mathrm{Y} \quad=\text { The even number test } \\
& \mathrm{N} \quad=\text { The number of students who take the test } \\
& \sum x y=\text { The total score of } \mathrm{x} \text { and } \mathrm{y}
\end{aligned}
$$


Table 1. Table of Reliability

\begin{tabular}{|c|c|}
\hline Range & Explanation \\
\hline $0.80-1.00$ & Very High \\
\hline $0.60-0.80$ & High \\
\hline $0.40-0.60$ & Low \\
\hline $0.00-0.40$ & Very Low \\
\hline
\end{tabular}

Furthermore, to know the index reliability of the test, the research analyzed the result by using Spearman Brown based on Arikunto (2012: 107) as follows:

$r_{11}=\frac{2 r 1 / 21 / 2}{(2+r / 21 / 2)}$

Where $r_{11}=$ The coefficient reliability for the total test

$r 1 / 21 / 2=$ The coefficient correlation between variable $\mathrm{x}$ and $\mathrm{y}$

\subsection{The Techniques of Data Analysis}

In analyzing the data, the writer analyzes the data of the ability of the eleventh-grade students of SMA Deli Murni Bandar Baru in using countable and uncountable nouns. To analyze the data, the writer follows the procedures that are suggested by Arikunto (2012:299) as follows:

- Calculating all of the students' score

- Calculating mean and standard deviation as follows

$M=\frac{\sum \int x}{N}$

Where:

$$
\begin{aligned}
\mathrm{M} & =\text { Mean } \\
\sum \int x & =\text { Total score of the students } \\
\mathrm{N} & =\text { The number of the students } \\
\mathrm{SD} & =\sqrt{\frac{\sum f x}{N}-\left[\frac{\sum f x}{N}\right]^{2}}
\end{aligned}
$$

Classifying the students' ability based on their group:

High ability $=>M+1 \mathrm{SD}$

Moderate ability = between $\mathrm{M}-1 \mathrm{SD}$

Low ability $=<(M+1 \mathrm{SD})(\mathrm{M}-1 \mathrm{SD})$

- Calculating the percentage of students who get high, moderate, and low ability: $\mathrm{P} \frac{R}{T} \times 100 \%$

Where: $\mathrm{P}=$ Percentage of the students' ability

$\mathrm{R}=$ The sum of the students who get high, moderate, and low ability

$\mathrm{T}=$ The sum of the students

\section{DATA ANALYSIS AND DISCUSSION}

The Description of Data 
This research was conducted at SMA Deli Murni Bandar Baru by online with 33 participants. The data collected in this research were the students' ability on using countable and Uncountable nouns.

\section{The Result of The Students' Ability}

According to Arikunto (2012: 299), the students' ability can be classified based on their group. Students' ability was categorized as high if their scores were higher than $83(\mathrm{M}+1 \mathrm{SD})$. Their abilities were categorized as moderate if their scores were in the range $40-83((M+1 S D)-(M+1 S D))$ and their abilities were categorized as low if their scores were lower than 40 (M+1 SD).

Table 2. Classification of Students in Using Countable and Uncountable Nouns

\begin{tabular}{|c|c|}
\hline The Ability & Countable and Uncountable Nouns \\
\hline \multirow{2}{*}{ High } & 5 \\
\cline { 2 - 2 } & $15 \%$ \\
\hline \multirow{2}{*}{ Moderate } & 24 \\
\cline { 2 - 2 } & $73 \%$ \\
\hline \multirow{2}{*}{ Low } & 4 \\
\cline { 2 - 2 } & \\
\cline { 2 - 2 }
\end{tabular}

As a result of the real test, the writer found out that the highest score got by the students in using Countable and Uncountable Nouns was 5 students and the lowest score was 32 .

Table 3. Mistakes Made Students Using Countable and Uncountable Nouns

\begin{tabular}{|c|c|c|c|c|c|c|}
\hline \multirow[t]{16}{*}{$\begin{array}{c}\text { Uncountable } \\
\text { Multiple } \\
\text { Choice }\end{array}$} & \multirow[t]{4}{*}{$\begin{array}{c}\text { Indefinite } \\
\text { Uncountable } \\
\text { Nouns }\end{array}$} & \multirow{2}{*}{\begin{tabular}{|c|}
$\begin{array}{c}\text { Item } \\
\text { Number }\end{array}$ \\
1
\end{tabular}} & \multirow{2}{*}{\begin{tabular}{|c|c|}
$\begin{array}{c}\text { The } \\
\text { numbers of } \\
\text { students }\end{array}$ \\
14
\end{tabular}} & \multirow{2}{*}{\begin{tabular}{|c|} 
The most \\
incorrect \\
answer
\end{tabular}} & \multirow{2}{*}{\begin{tabular}{|l|}
$\begin{array}{c}\text { The correct } \\
\text { answered }\end{array}$ \\
Time
\end{tabular}} & \multirow{2}{*}{\begin{tabular}{|c|} 
Percentage \\
$19 \%$ \\
\end{tabular}} \\
\hline & & & & & & \\
\hline & & 2 & 7 & Waters & Water & \\
\hline & & 3 & 8 & Bloods & Blood & \\
\hline & & 4 & 11 & Salts & Salt & \\
\hline & & 5 & 15 & News' & News & \\
\hline & & 6 & 16 & Efforts & Effort & \\
\hline & & 7 & 22 & Advise & Advice & \\
\hline & & 8 & 5 & $\begin{array}{l}\text { Plural } \\
\text { countable }\end{array}$ & Uncountable & \\
\hline & Quantifier & 9 & 8 & Sugars & Sugar & $14 \%$ \\
\hline & Uncountable & 10 & 13 & Water & Air & \\
\hline & & 11 & 15 & $\begin{array}{l}\text { Water, salt } \\
\text { floor }\end{array}$ & $\begin{array}{l}\text { Water, floor, } \\
\text { salt }\end{array}$ & \\
\hline & & 12 & 15 & Package & Slice & \\
\hline & & 13 & 15 & Piece & Bar & \\
\hline & & 14 & 8 & Bowl & Glass & \\
\hline & & 15 & 9 & Appleas & Aplle & $4 \%$ \\
\hline
\end{tabular}


KAIROS ELT JOURNAL, Vol. 5 No. 1 April 2021

Copyright $\bigcirc 2021$, ISSN: 2580-4278

\begin{tabular}{|c|c|c|c|c|c|c|}
\hline $\begin{array}{c}\text { Countable } \\
\text { Multiple } \\
\text { Choice }\end{array}$ & $\begin{array}{l}\text { Singular } \\
\text { countable } \\
\text { nouns }\end{array}$ & 16 & 14 & pen & A pen & \\
\hline & \multirow{3}{*}{$\begin{array}{l}\text { Regular } \\
\text { plural } \\
\text { countable }\end{array}$} & 17 & 20 & Car & Cars & $11 \%$ \\
\hline & & 20 & 16 & Method & Methods & \\
\hline & & 23 & 21 & Wifes & Wives & \\
\hline & \multirow{6}{*}{$\begin{array}{l}\text { Irregular } \\
\text { plural } \\
\text { countable }\end{array}$} & 24 & 22 & Address & Addresses & $19 \%$ \\
\hline & & 25 & 18 & Library & Libraries & \\
\hline & & 18 & 19 & Mouses & Mice & \\
\hline & & 19 & 17 & Womans & Women & \\
\hline & & 21 & 10 & Teeth/tooth & Tooth/teeth & \\
\hline & & 22 & 12 & Feets & Feet & \\
\hline \multirow{8}{*}{$\begin{array}{c}\text { Countable } \\
\text { Essay }\end{array}$} & \multirow{3}{*}{$\begin{array}{l}\text { Regular } \\
\text { plural }\end{array}$} & 2 & 15 & Potatos & Potatoes & $21 \%$ \\
\hline & & 3 & 6 & Book & Books & \\
\hline & & 4 & 18 & Magazine & Magazines & \\
\hline & & 5 & 24 & Fish & Fishes & \\
\hline & & 7 & 17 & Language & Languages & \\
\hline & & 8 & 11 & Friend & Friends & \\
\hline & & 9 & 15 & Song & Songs & \\
\hline & $\begin{array}{l}\text { Irregular } \\
\text { plural }\end{array}$ & 1 & 19 & Gooses & Geese & $12 \%$ \\
\hline
\end{tabular}

\subsection{Discussion}

As a result of the research showed that 5 students $(15 \%)$ belong to the high category, 24 students (73\%) to moderate category, and 4 students (12\%) to the low category. Therefore based on the group, the ability of the eleventh-grade students of SMA Deli Murni Bandar Baru on using Countable and Uncountable was moderate $(73 \%)$. But based on the totality of the students the writer found 61,39 for mean and 21, 62 for standard deviation.

There were 8 students who got a score above 75 who passed the Minimal Criterion Mastery (KKM) from 33 students who followed the test. It means that the second-year students at SMA Deli Murni Bandar Baru are not able yet to use Countable and Uncountable Nouns because only $24 \%$ (students) who passed the minimal criterion mastery whereas according to the rule, there must be $70 \%$ of the total students who score above 75 to be said "able". Therefore, it can be concluded that the eleventh-grade students of SMA Deli Murni Bandar Baru are not yet able to use Countable and Uncountable Nouns.

Based on table 4.2 the total incorrect answers made by students in Countable and uncountable Nouns was 502. The table showed that the percentage of mistakes made by students using Countable and Uncountable Nouns in Uncountable multiple choice was $20 \%$, and the percentage of students' mistakes made by students in Countable multiple was $47 \%$, the last is the percentage mistakes made by students in Countable Essay was $33 \%$. So the most mistakes made by students in using Countable and Uncountable Nouns was in Countable Multiple Choice, the percentage was $47 \%$. 


\section{CONCLUTIONS AND SUGGESTIONS}

\subsection{Conclusions}

The conclusions of this research are presented based on the data which have been analyzed in the previous chapter. From all the data analysis about the ability of the eleventh-grade students of SMA Deli Murni Bandar Baru in using Countable and Uncountable Nouns, it can be concluded as follows:

1. Based on the total number of students, the writer found out only 8 students who get a score above 75 and passed the Minimal Criterion Mastery (KKM). It means that the eleventh-grade students of SMA Deli Murni Bandar Baru are not yet able to use Countable and Uncountable Nouns because of only $24 \%$ of the total students who can do the test well. Whereas 76 of the students can not do the test well. The regulation of saying ability is fulfilled if $70 \%$ of the total number of the students can do the test well

2. Based on the ranking group the ability of the eleventh-grade students of SMA Deli Murni Bandar Baru in using Countable and Uncountable Nouns was moderate category $(73 \%)$ with a score in the range $40-83$. The writer found out that 5 students belong to the high category $(15 \%)$ with the score $>83$, and 4 students to low category $(14 \%)$ with the score $<40$.

3. Based on the total incorrect answers made by the students in the Countable and Uncountable Test was 502. The table showed that the percentage of this mistakes made by students using Countable and Uncountable Nouns in Uncountable

4. Multiple choice was $33 \%$, and the percentage mistakes made by students in Countable Multiple Choice was $34 \%$, the last is in Countable Essay the percentage mistakes made by students was $33 \%$. Based on the checking and analyzing the real test, some students were difficult to distinguish between Countable and Uncountable Nouns. The students used plural form in Uncountable words by adding the suffix -s and -es. For example "information" and "news change to be "informations" and "newses". Based on analyzing the writer most of the students made a mistake in changing the singular form into irregular plural form. For example, "person" in the singular to be "persons" in the plural.

\section{BIBLIOGRAPHY}

Arikunto, S. 2012. Dasar-dasar Evaluasi Pendidikan Edisi Kedua. Jakarta: PT Bumi Aksara.

Atlee, N. 2005. The Absolutely Essential Grammar Guide. Waco: Prufrock Press Inc.

Bestiana, y. \& Achyani, M. 2015, Big Book Bahasa Inggris SMP. Jakarta Selatan: Cmedia Imprint Kawan Pustaka.

Bian, J. \& Guo, Y. 2019. Social Web and Health Research Benefits Limitations and Best Practices. Gainesville: Springer. 
Blakesley, d. \& Hoogeveen, J.L. 2012. Wadsworth Cengage Learning. Boston: Wadsworth.

2012. Writing: A Manual for the Digital Age with Exercises Brief. Boston: Wadsworth.

Chelladuari, P. 2006. Human Resource Management in Sport and Recreation. Champaign: Human Kinetics.

Crystal. 2019. The Cambridge Encyclopedia of the English Language. Cambridge: Cambridge University Express.

Dalmolin, H. 2009. The English Grammar with Phonetics, Morphology and Syntax. Mustang: Tata Publishing \& Enterprises, LLC. 2020. DRDO Multi-Tasking Staff (CEPTAM) Tier I \& II Pariksha Guide 2020 Hindi Edition. New Delhi: Disha Publication.

Denham \& Lobeck. 2010. Heinemann English Prosionary: The Most Comprehensive School Dictionary. London: Heinemann.

Gangal, J.K. 2011. A Practical Course for Developing Writing Skill in English. Delhi: PHI Learning Private Limited.

Giri, Sharman \& D’Angelo. 2020. Functional Variations In English: Theoritical Confiderations and Practical Challenges. Australia: Springer.

Haffman, E. \& Farrel, D. 2007. Operation \& Management Principle for Contact Centres. Cape Town: Juta \& Co Ltd.

Hall, H.L. \& Aimone, L.H. 2009. High School Journalism. New York: Rosen Publishing.

Harber \& Lobeck. 2010. Linguistics for Everyone. Boston: Wadsworth Cengage Learing.

Johnson, B \& Christensen, L. 2012. Educational Research: Quantitative, Qualitative, and Mixed Approaches. California: SAGE Publication, Inc.

Lapworth, K. 2011. The writer's Guide to Good Style. London: Hodder Education.

Littlejohn, A. \& Pegler, C. 2007. Preparing for Blended e-learning. Oxon: Routledge.

Lobb, N. 2002. Find the Errors! II: Proofreading Activities. Portland: J. Weston Walch, Publisher.

Mandell, S.R. \& Kirszner, L. G. 2008. The Concise Wadsworth Handbook. Philadelpia: Thomson Learning, Inc. 
Pelt, M.V.V. 2010. English Grammar to ACE Biblical Hebrew. Michigan: Zondervan.

Ramadass, P \& Waruni, A. W. 2014. Research and Writing Across the Disciplines. Chennai: MJP Publishers.

Ribes, R. \& Mejia, S. 2008. Cardiovascular English. Cardoba: Springer.

Robbins, S. \& Judge, T. A. 2014. Organisational Behaviour. French Forest: Pearson Australia.

Sanford, A. 2012. Universal Design as a Rehabilitation Strategy: Designed for the Ages. New York: Springer Publishing Company.

Schmidt, N. A. 2012. Evidence-Based Practice for Nurses. Sudbury: Jones \& Bartlett Learning.

Singh, R. 2019. Essential English for Competitive Examinations. New Delhi: Disha Publication.

Singh, V.P. 2015. Objective General English. Delhi : PHI Learning Privat Limited.

Sinha, N. K. 2010. The Pearson Complete Guide to CAT. New Delhi: Dorling Kindersley.

Snape, N. \& Kupisch, T. 2017. Second Language Acquisition. London: Macmillan Publishers Limited.

Strazny, F. 2005. Encyclopedia of Linguistics 2V. New York: Fitzray Dearborn.

Sullivan, L.E. 2009. The SAGE Glossary of the Social and Behavioral Sciences. California: SAGE Publications, Inc.

Wallwork, A. 2015. English for Research: Usage, Style and Grammar. London: Springer Science + Business Media.

Zaim, M. 2013. Asesmen Otentik: Implementasi dan Permasalahannya dalam Pembelajaran Bahasa Inggris di Sekolah Menengah. Proceeding of the International Seminar on Language and Arts, Padang: 5-6 October 2013, Page. 9. 